\title{
ZnO AND Ag-ZnO CRYSTALS: SYNTHESIS, CHARACTERIZATION, AND APPLICATION IN HETEROGENEOUS PHOTOCATALYSIS
}

\author{
Adriana Campano Lucilha ${ }^{a}$, Marcelo Rodrigues da Silvab ${ }^{b}$, Rômulo Augusto Andoc ${ }^{c}$ Luiz Henrique Dall'Antonia ${ }^{a}$ and Keiko \\ Takashima ${ }^{\mathrm{a}, *}$ \\ aDepartamento de Química, Universidade Estadual de Londrina, 86057-970 Londrina - PR, Brasil

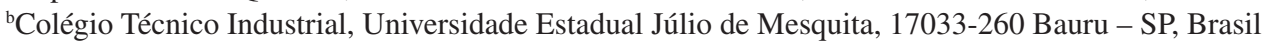 \\ 'Instituto de Química, Universidade de São Paulo, 05508-000 São Paulo - SP, Brasil
}

Recebido em 28/07/2015; aceito em 22/12/2015; publicado na web em 11/03/2016

\begin{abstract}
$\mathrm{ZnO}$ and $\mathrm{Ag}-\mathrm{ZnO}$ were synthesized in a simple and efficient manner by thermal decomposition of zinc oxalate and silver/zinc mixed oxalate. The influence of the addition of metallic silver on $\mathrm{ZnO}$ particles and the effect of temperature in the thermal treatment were investigated. The samples were characterized by thermogravimetric analysis, Raman, X-ray diffraction, scanning electron microscopy, energy dispersive X-ray spectroscopy, specific surface area (Brunauer-Emmett-Teller) and diffuse reflectance spectroscopy. The photocatalytic activity of these materials in the decolorization of direct red 23 diazo dye was studied. The complete conversion into oxides from oxalates at lower temperatures was determinant in the photocatalytic efficiency of both the oxides. The presence of silver in zinc oxide, treated at $400{ }^{\circ} \mathrm{C}$, more than doubled the rate constant of diazo dye decolorization $\left(6.87 \times 10^{-3} \mathrm{~min}^{-1}\right)$ with respect to $\mathrm{ZnO}$, treated at $600{ }^{\circ} \mathrm{C}$, resulting in $3.07 \times 10^{-3} \mathrm{~min}^{-1}$ under UV irradiation at $30^{\circ} \mathrm{C}$.
\end{abstract}

Keywords: oxide semiconductor; surface modification; thermal treatment; direct red 23.

\section{INTRODUCTION}

The discharge of wastewaters with high concentration of dyes has created severe environmental pollution problems by releasing toxic and potential carcinogenic substances into the aquatic medium. ${ }^{1,2}$ It has been estimated that about $60 \%$ are azo dyes, characterized by one or more azo $(-\mathrm{N}=\mathrm{N}-)$ groups bonded to the benzenic or naphtalenic rings. ${ }^{3}$ Among the advanced oxidation processes, the heterogeneous photocatalysis mediated by oxide semiconductors is regarded as a promising method for the effluent treatment. ${ }^{1,2}$ The semiconductor, under ultraviolet light irradiation, promotes electron from the valence band to the conduction band to give electron-hole pair in order to produce hydroxyl radical and to attack organics present at or near the surface. On the other hand, as the separation and recombination between these charge carriers are competitive, the photocatalytic activity becomes more effective when the recombination is hindered. ${ }^{4}$

In this context the zinc oxide, an $n$-type semiconductor, has been investigated for the photocatalytic application due to some interesting characteristics such as band gap energy of $3.37 \mathrm{eV}, 5$ exciton binding energy of $60 \mathrm{meV}$, high electronic mobility, good transparency, environmental stability, low cost, in comparison to other metallic oxides and mainly by the possibility of simple synthesis. ${ }^{5}$ However, the $\mathrm{ZnO}$ efficiency can be lowered owing to the photogenerated charged carriers $\left(h^{+} / e^{-}\right)$recombination on the surface. ${ }^{6,7}$

Therefore, the $\mathrm{ZnO}$ surface modification, using metallic silver $(\mathrm{Ag}-\mathrm{ZnO})$ has been investigated with the aim to intensify the photocatalytic capacity of zinc oxide. ${ }^{7-10}$ Taking into place that silver can capture the photogenerated electrons from the semiconductor, the charge carriers recombination can be inhibited. So, the photogenerated hole $\left(h^{+}\right)$can react with the adsorbed water molecule (or hydroxide anion) to generate hydroxyl radical, $\mathrm{HO}^{\bullet} .{ }^{1}$ The hydroxyl radical is considered extremely strong oxidant agent with redox potential of $+2.8 \mathrm{~V},{ }^{2}$ which can mineralize the azo dyes to innocuous compounds. Zhai et al. ${ }^{11}$ reported the meaningful enhancement of the

*e-mail: keiko@uel.br
$\mathrm{ZnO}$ photocatalytic activity in the presence of silver $(\mathrm{Ag}-\mathrm{ZnO})$ for the Rhodamine B dye degradation under solar light. Liang et al. ${ }^{12}$ also verified the photocatalytic activity increase for the $\mathrm{Ag} / \mathrm{ZnO}$ in comparison to the $\mathrm{ZnO}$ and $\mathrm{TiO}_{2}$ commercial in order to degrade the Rhodamine B under UV irradiation. Bouzid et al. ${ }^{13}$ presented the $\mathrm{ZnO}$ photocatalytic activity in the presence of different silver percentages, whose best results for the methylene blue degradation took place to that containing $1 \% \mathrm{Ag}$ after $150 \mathrm{~min}$ UV irradiation.

This work had as objective to study the formation of pure $\mathrm{ZnO}$ and mixed with silver by oxalate decomposition at different temperatures in order to understand the temperature influence in the structures and interactions between $\mathrm{ZnO}$ and $\mathrm{Ag}$. The photocatalytic activity of these semiconductors was investigated by means the direct red 23 diazo dye (DR23), Figure 1S, decolorization as a function of the irradiation time on the synthesized material surface under UV light exposure at $30^{\circ} \mathrm{C}$.

\section{EXPERIMENTAL}

\section{Materials}

All the reactants were of analytical purity and used without previous purification as zinc oxide ( $\mathrm{ZnO}$, Nuclear, PA), hexa-hydrated zinc nitrate $\left(\mathrm{Zn}\left(\mathrm{NO}_{3}\right)_{2} \cdot 6 \mathrm{H}_{2} \mathrm{O}\right.$, Synth, $\left.99.4 \%\right)$, dehydrated oxalic acid $\left(\mathrm{H}_{2} \mathrm{C}_{2} \mathrm{O}_{4} \cdot 2 \mathrm{H}_{2} \mathrm{O}\right.$, Synth, 99.5\%) and silver nitrate $\left(\mathrm{AgNO}_{3}\right.$, Vetec, 99.8\%). Direct red 23 diazo dye $\left(\mathrm{C}_{35} \mathrm{H}_{27} \mathrm{~N}_{7} \mathrm{~S}_{2} \mathrm{O}_{10} \mathrm{Na}_{2}\right)$, C. I. 29160 $\left(2.54 \times 10^{4} \mathrm{~cm}^{-1} \mathrm{~mol}^{-1} \mathrm{~L}, 0.999\right)^{14}$ was a gift from A. Chimical. All the solutions were prepared using purified water (Elga USF CE).

\section{Synthesis of zinc oxide pure and mixed with silver}

Zinc oxide was synthesized, taking $0.40 \mathrm{~mol} \mathrm{~L}^{-1}$ zinc nitrate and $0.60 \mathrm{~mol} \mathrm{~L}^{-1}$ oxalic acid of equal volume, $100 \mathrm{~mL}$. These solutions were boiled separately until the boiling point. ${ }^{15}$ Zinc nitrate solution was added to oxalic acid solution in this temperature and the heating was immediately interrupted. The resulting mixture was maintained 
under stirring (300 rpm - Fisatom 752) until room temperature. The precipitated was filtered in a vacuum (Schleicher \& Schuell, $47 \pm 0.5$ $\mathrm{mm}$ diameter, $0.20 \mu \mathrm{m}$ pore) and washed by several times with distilled water, overnight dried in air followed by heating at $100{ }^{\circ} \mathrm{C}$ for $3 \mathrm{~h}$ (Biopar S150SD). ${ }^{15}$ Approximately $2.0 \mathrm{~g}$ of the compound was introduced in the muffle (Marconi MA385) at $10{ }^{\circ} \mathrm{C} \mathrm{min}^{-1}$ until reaching the desired temperature $\left(200,400,600,800\right.$, and $\left.1000{ }^{\circ} \mathrm{C}\right)$ during $12 \mathrm{~h}$. Similar procedure was followed to synthesize zinc oxide mixed with silver, adding $50 \mathrm{~mL}$ of the $\mathrm{Zn}\left(\mathrm{NO}_{3}\right)_{2} \cdot 6 \mathrm{H}_{2} \mathrm{O}$ and $50 \mathrm{~mL}$ of the $\mathrm{AgNO}_{3}(17.9 \% \mathrm{Ag} \mathrm{wt})$, both with $0.40 \mathrm{~mol} \mathrm{~L}^{-1}$, in $100 \mathrm{~mL}$ of the oxalic acid $0.60 \mathrm{~mol} \mathrm{~L}^{-1}$, and heated thermally at 400, 600, and $1000{ }^{\circ} \mathrm{C}$ during $12 \mathrm{~h}$.

\section{Characterization}

The thermogravimetric and differential thermal analyses were carried out in a SEIKO 6300 thermal analyzer in air atmosphere ranging from 30 to $1200{ }^{\circ} \mathrm{C}$ with a heating rate of $10{ }^{\circ} \mathrm{C} \mathrm{min}{ }^{-1}$. Alumina was used as reference substance. The vibrational spectra were obtained from a Bruker FT-Raman RFS 100 spectrometer with excitation at $1064 \mathrm{~nm}$, obtained through the Nd/YAG laser of 200 $\mathrm{mW}$. The scanning system with accumulation of $256 \mathrm{scans}$ and $2 \mathrm{~cm}^{-1}$ spectral resolution were used. The X-ray diffratogram were obtained from the powder method, using a Rigaku RINT 2000 Diffractometer with $\mathrm{Cu}-\mathrm{K} \alpha_{1}$ radiation source $(1.5418 \AA)$ and collected with average of three successive scanning with $1^{\circ} \mathrm{min}^{-1}$ speed. The qualitative determination of the elements and its distribution were carried out by X-Ray dispersive energy spectrometry, EDS (Philips FEI Quanta 200). The morphology and structural organization were characterized by scanning electron microscopy, SEM (Philips FEI Quanta 200). The specific surface area and pore volume were determined by Brunauer-Emmett-Teller (BET) method, using a Quantachrome NovaWin version 10.01 . The samples were pre-treated at $300{ }^{\circ} \mathrm{C}$ in a vacuum during $3 \mathrm{~h}$. The band gap energy $\left(\mathrm{E}_{\mathrm{g}}\right)$ was determined from the UV-Vis diffuse reflectance spectra in a Shimadzu UV-3101 PC, using the Kubelka-Munk model, which relates the sample reflectance $\left(\mathrm{F}(\mathrm{R})^{1 / 2}\right)$ and the excitation energy of emitted photon. ${ }^{16}$

\section{Photocatalytic activity}

The photocatalyst $\left(2.0 \mathrm{~g} \mathrm{~L}^{-1}\right)$ was introduced in a double wall borosilicate reactor, opened to the atmosphere, containing $150 \mathrm{~mL}$ of $7.5 \times 10^{-5} \mathrm{~mol} \mathrm{~L}^{-1}$ direct red 23 diazo dye (DR23). This suspension was stirred at $600 \mathrm{rpm}$ (Fisatom 752) during $60 \mathrm{~min}$ in the dark at $30.0 \pm 0.1^{\circ} \mathrm{C}$ (Microquímica MQ8TC), inside a wooden box (50x50x50 $\mathrm{cm}$ ) covered internally with aluminum foil. The suspension irradiation was carried out in the same reactor using $\mathrm{Hg}$ vapor lamp without bulb $(125 \mathrm{~W})$, positioned horizontally at $22 \mathrm{~cm}$ from the reactor. The irradiance $\left(1600.0 \pm 20.0 \mu \mathrm{W} \mathrm{cm}{ }^{-2}\right)$ was measured through the radiometer (Topcon UVR-2). Aliquots $(1.10 \mathrm{~mL})$ of decolorized DR23 were removed at predetermined time intervals, filtered (Millipore -0.22 $\mu \mathrm{m})$, and monitored by UV-Vis spectrophotometry from 200 to 900 $\mathrm{nm}$ (Ocean Optics USB4000) at $503 \mathrm{~nm}$. The decolorization rate constant, $k_{o b s}$, was determined graphically under pseudo-first order conditions ${ }^{17}$ at $30{ }^{\circ} \mathrm{C}$.

\section{RESULTS AND DISCUSSION}

\section{Materials characterization}

The thermo-gravimetric and differential thermal analyses at air atmosphere for hydrated zinc oxalate $\left(\mathrm{m}_{\text {sample }} 10.4 \mathrm{mg}\right.$ ), Figure 1a, showed that the thermal decomposition occurred at two well-defined steps of mass loss. The first one (16.4\%) was an endothermic process and corresponded to a moisture $\left(122^{\circ} \mathrm{C}\right)$ and hydration $\left(146^{\circ} \mathrm{C}\right)$ of water molecules. The second mass loss $(39.5 \%)$ was related to the exothermic decomposition of the zinc oxalate in $\mathrm{CO}_{2}$ and $\mathrm{CO}$ at 398 ${ }^{\circ} \mathrm{C}$. The residual mass of $\mathrm{ZnO}$ was $44.1 \%$. The zinc oxide formation is displayed in Reaction 1.

$$
\mathrm{ZnC}_{2} \mathrm{O}_{4} \cdot 1.67 \mathrm{H}_{2} \mathrm{O} \rightarrow \mathrm{ZnC}_{2} \mathrm{O}_{4} \rightarrow \mathrm{ZnO}
$$

Ahmad et al. ${ }^{18}$ verified similar behavior for the $\mathrm{ZnO}$ synthesis from $\mathrm{ZnC}_{2} \mathrm{O}_{4}$, whose uniform $\mathrm{ZnO}$ nanoparticles were found at $400{ }^{\circ} \mathrm{C}$.
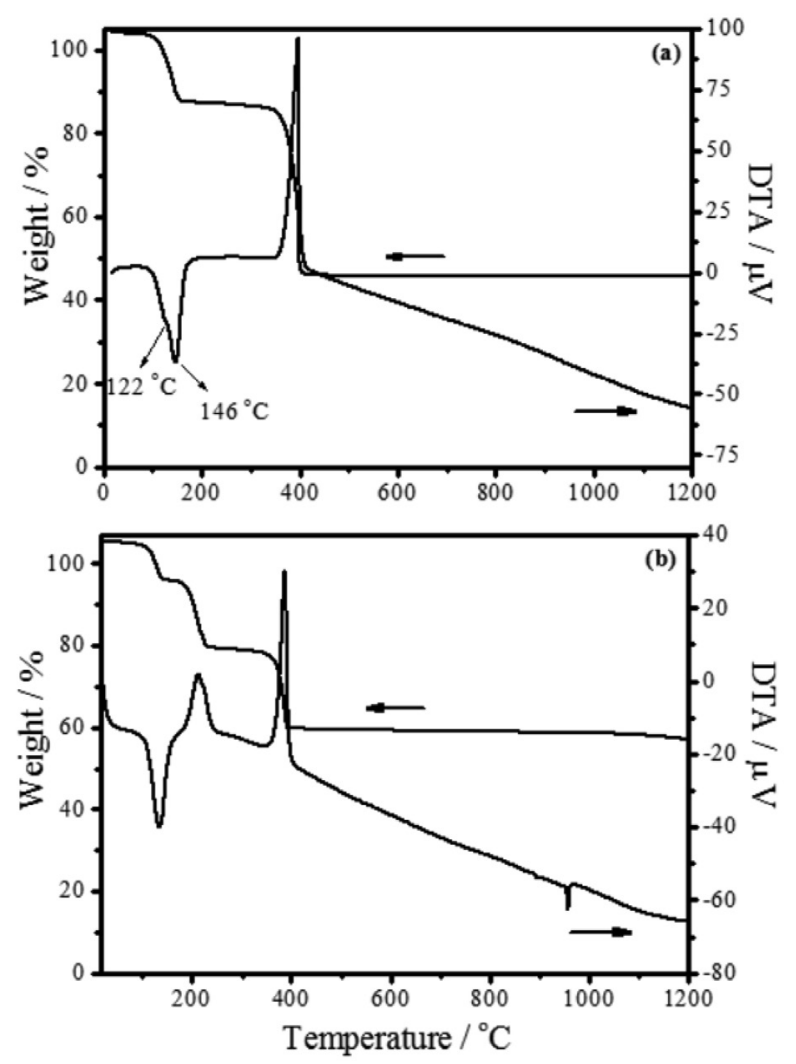

Figure 1. TGA/DTA curves of (a) $\mathrm{ZnC}_{2} \mathrm{O}_{4}$, and (b) $\mathrm{Ag}_{2} \mathrm{C}_{2} \mathrm{O}_{4}-\mathrm{ZnC}_{2} \mathrm{O}_{4}$

The thermo-gravimetric curve of the zinc and silver mixed oxalate $\left(\mathrm{Ag}_{2} \mathrm{C}_{2} \mathrm{O}_{4}-\mathrm{ZnC}_{2} \mathrm{O}_{4}\right)$ in air atmosphere $\left(\mathrm{m}_{\text {sample }} 10.5 \mathrm{mg}\right)$, Figure $1 \mathrm{~b}$, shows that the thermal decomposition occurred in three steps. The initial loss, $9.1 \%$, at $134{ }^{\circ} \mathrm{C}$ was an endothermic process with $5 / 2$ mol dehydration. The second loss, $16.0 \%$, at $212{ }^{\circ} \mathrm{C}$ was related to the exothermic decomposition of $\mathrm{Ag}_{2} \mathrm{C}_{2} \mathrm{O}_{4}$ in $\mathrm{Ag}_{2} \mathrm{O}$. The third one of $18.6 \%$ at $387{ }^{\circ} \mathrm{C}$ corresponded to the exothermic decomposition of $\mathrm{ZnC}_{2} \mathrm{O}_{4}$ and $\mathrm{Ag}_{2} \mathrm{O}$. The Ag-ZnO formation is represented in Reaction 2.

$\mathrm{Ag}_{2} \mathrm{C}_{2} \mathrm{O}_{4} \cdot \mathrm{ZnC}_{2} \mathrm{O}_{4} \cdot 5 /{ }_{4} \mathrm{H}_{2} \mathrm{O} \rightarrow \mathrm{Ag}_{2} \mathrm{C}_{2} \mathrm{O}_{4} \cdot \mathrm{ZnC}_{2} \mathrm{O}_{4} \quad(\times 2)$

$2 \mathrm{Ag}_{2} \mathrm{C}_{2} \mathrm{O}_{4}+2 \mathrm{ZnC}_{2} \mathrm{O}_{4} \rightarrow 2 \mathrm{Ag}_{2} \mathrm{O}+2 \mathrm{ZnC}_{2} \mathrm{O}_{4} \rightarrow 4 \mathrm{Ag}+2 \mathrm{ZnO}$

The last process, verified by differential thermal analyses at $957{ }^{\circ} \mathrm{C}$, was relative to the endothermic process of metallic silver fusion $\left(957{ }^{\circ} \mathrm{C}\right)$. As in the zinc oxide as well as zinc-silver oxide formation, there was not mass variation until $1200{ }^{\circ} \mathrm{C}$ and this indicates that the reaction was complete and no solid state reaction or phase transition occurred.

Raman scattering spectra indicated that, when the $\mathrm{ZnC}_{2} \mathrm{O}_{4}$ was heated at $200{ }^{\circ} \mathrm{C}$ during $12 \mathrm{~h}$ was not enough in order to produce 
$\mathrm{ZnO}$, considering that the sample spectrum is similar to zinc oxalate as shown in Figure 2a. At $400{ }^{\circ} \mathrm{C}$, Figure 2a, the dominant spectrum was of $\mathrm{ZnO}$ with fluorescence, due to the incomplete burn of the zinc oxalate. On the other hand, the spectrum did not present fluorescence from $600{ }^{\circ} \mathrm{C}$ until $1000{ }^{\circ} \mathrm{C}$, in which are shown only frequencies corresponding to the wurtzite structure at $437 \mathrm{~cm}^{-1}$ $\left(\mathrm{E}_{2}^{\text {high }}\right)$ and a large band from 1000 to $1200 \mathrm{~cm}^{-1}$. These bands were attributed respectively to the oxygen movement and to the $\mathrm{ZnO}$ multi-phonons modes. ${ }^{5,19}$

The Raman spectra of Ag-ZnO sample, Figure 2b, presented the characteristic stretchings at $437 \mathrm{~cm}^{-1}$ and $1000-1200 \mathrm{~cm}^{-1}$ for $\mathrm{ZnO}$ only at $1000{ }^{\circ} \mathrm{C}$, attributed to the larger silver amount on the oxide surface at $400{ }^{\circ} \mathrm{C}$ and $600{ }^{\circ} \mathrm{C}$. The partial fusion of $\mathrm{Ag}$ at $957{ }^{\circ} \mathrm{C}$ justifies the appearing of the $\mathrm{ZnO}$ characteristic bands at $1000{ }^{\circ} \mathrm{C}$.
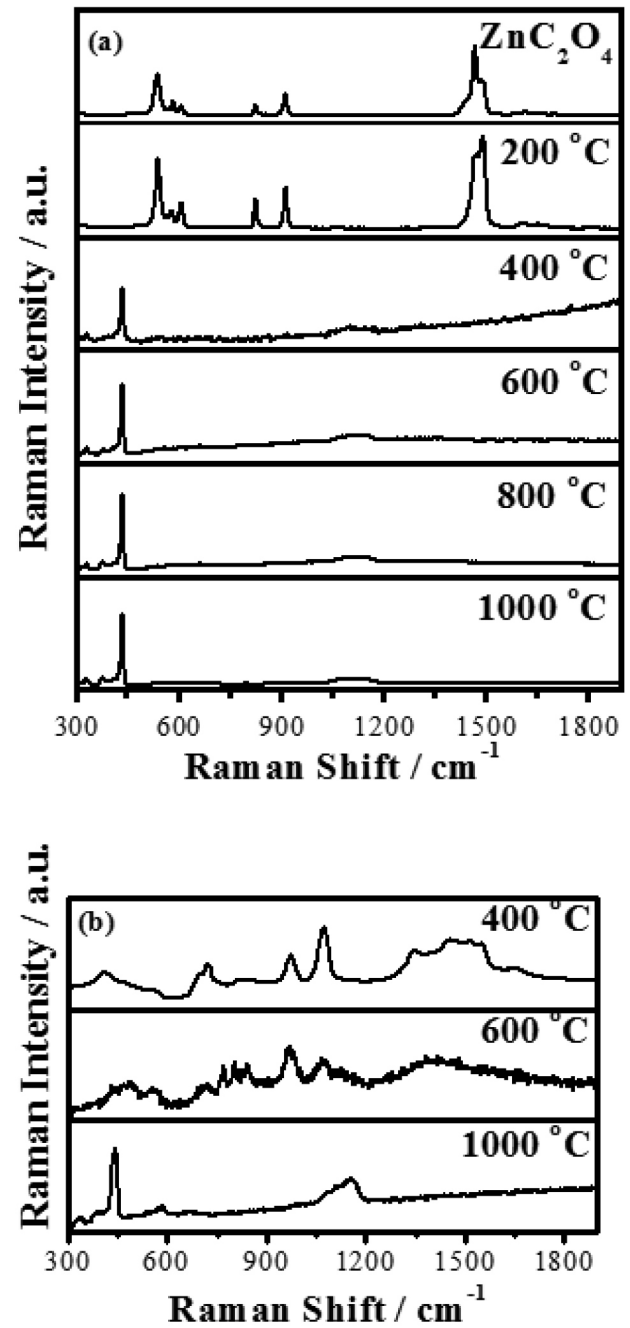

Figure 2. Raman spectra of (a) pure zinc oxalate and heated thermally (200, $400,600,800$ and $1000{ }^{\circ} \mathrm{C}$ ) for $12 \mathrm{~h}$, and (b) synthesized $\mathrm{Ag}$-ZnO at different temperatures $\left(400,600\right.$, and $\left.1000^{\circ} \mathrm{C}\right)$ for $12 \mathrm{~h}$

Figure 3 presents X-ray diffractograms of zinc oxalate, Figure $3 \mathrm{a}$, and of samples treated thermally, Figure $3 \mathrm{~b}-\mathrm{f}$. Only characteristic peaks of the zinc oxalate at $2 \theta$ as $23.4^{\circ}(002), 30.2^{\circ}(402)$, $35.1^{\circ}(021), 48.3^{\circ}(023), 40.5^{\circ},(022)$ and $43.4^{\circ}(221)$ were observed at $200{ }^{\circ} \mathrm{C}$, Figure $3 \mathrm{~b} \cdot{ }^{18,20} \mathrm{The} \mathrm{ZnO}$ synthesis from $\mathrm{ZnC}_{2} \mathrm{O}_{4}$ occurred from $400{ }^{\circ} \mathrm{C}$, presenting $2 \theta$ peaks at $31.7^{\circ}(100), 34.4^{\circ}(002), 36.3^{\circ}$ (101), $47.5^{\circ}(102), 56.6^{\circ}(110), 62.8^{\circ}(103), 66.3^{\circ}(200), 67.9^{\circ}(112)$ and $68.9^{\circ}(201)$, Figure $3 \mathrm{c}-\mathrm{f}$, characterized by the crystalline structure of wurtzite. ${ }^{5}$ This structure belongs to the hexagonal system
P63mc (186) crystallographic class $6 \mathrm{~mm}$, whose lattice parameters are $\mathrm{a}=\mathrm{b}=3.2562 \AA$ and $\mathrm{c}=5.2105 \AA$ (PDF code 01-079-2205). All these results are consistent with respect to those obtained by thermogram, Figure 1, and by Raman scattering spectra, Figure 2. So, the samples treated at $400,600,800$, and $1000{ }^{\circ} \mathrm{C}$ presented crystal structure of $\mathrm{ZnO}$.

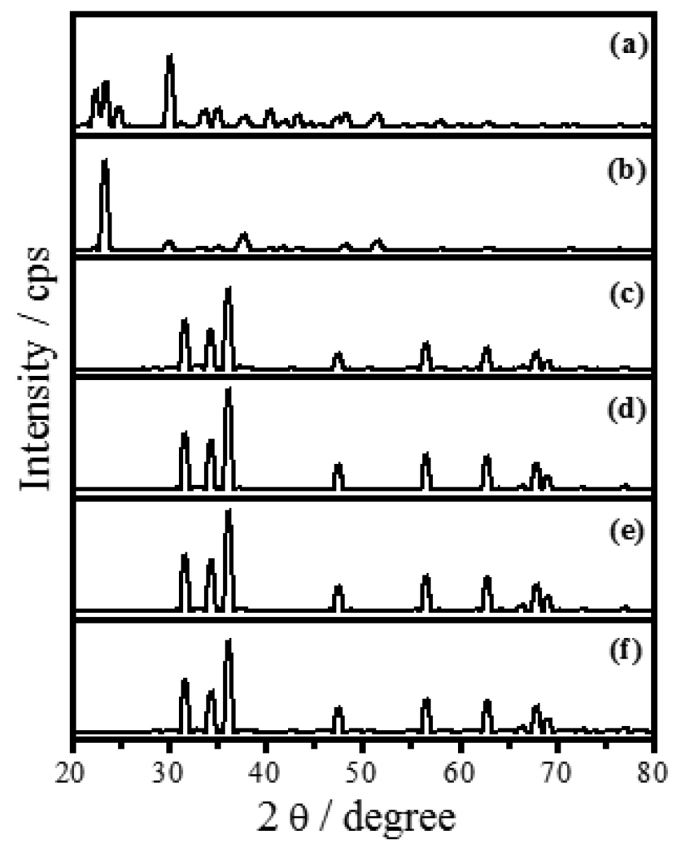

Figure 3. XRD patterns of (a) zinc oxalate and heated at (b) $200{ }^{\circ} \mathrm{C}$, (c) $400{ }^{\circ} \mathrm{C},(d) 600{ }^{\circ} \mathrm{C}$, (e) $800{ }^{\circ} \mathrm{C}$, and (f) $1000{ }^{\circ} \mathrm{C}$ for $12 \mathrm{~h}$

The diffratograms of the unheated sample formed from the mixture of zinc nitrate and silver nitrate, Figure $4 a$, indicates the existence of silver oxalate and zinc oxalate $\left(\mathrm{Ag}_{2} \mathrm{C}_{2} \mathrm{O}_{4}-\mathrm{ZnC}_{2} \mathrm{O}_{4}\right)$ phases.

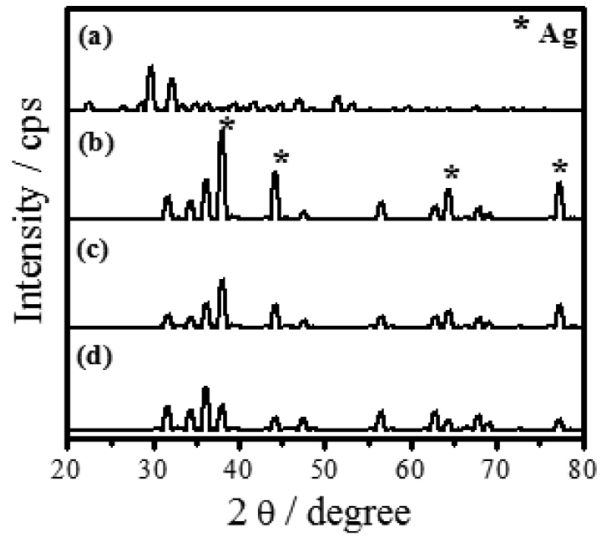

Figure 4. XRD patterns of (a) synthesized mixed oxalate $\left(\mathrm{ZnC}_{2} \mathrm{O}_{4}-\mathrm{Ag}_{2} \mathrm{C}_{2} \mathrm{O}_{4}\right)$ and heated thermally in (b) $400{ }^{\circ} \mathrm{C}$, (c) $600{ }^{\circ} \mathrm{C}$, and (d) $1000{ }^{\circ} \mathrm{C}$ for $12 \mathrm{~h}$

The majority of the peaks belongs to the silver oxalate, that presents a primitive monoclinic crystalline system, spatial group $\mathrm{P} 2{ }_{1} / \mathrm{n}$ (14) and estimates lattice parameters of $\mathrm{a}=9.368 \AA, \mathrm{b}=$ $6.203 \AA$ and $\mathrm{c}=3.455 \AA$ (JCPDFWIN 22-1335). According to the thermogram displayed in Figure 1b, the conversion from mixed oxalate $\left(\mathrm{Ag}_{2} \mathrm{C}_{2} \mathrm{O}_{4}-\mathrm{ZnC}_{2} \mathrm{O}_{4}\right)$ to $\mathrm{ZnO}$ and $\mathrm{Ag}$ occurs at $400{ }^{\circ} \mathrm{C}$. These results were confirmed by $\mathrm{XRD}$, because as the wurtzite phase peaks of $\mathrm{ZnO}$ as fcc of metallic silver with peaks characteristics in $2 \theta$ at $38.1^{\circ}(111), 44.2^{\circ}(200), 64.4^{\circ}(220)$ and $77.4^{\circ}$ (311), JCPDS No. 04-783, were observed. The metallic silver was produced from the 
$\mathrm{Ag}_{2} \mathrm{O}$ decomposition in the $\mathrm{ZnO}$ environment at $387^{\circ} \mathrm{C}$, as shown in Reaction 3.

$$
\mathrm{ZnO}_{(\mathrm{s})}+\mathrm{Ag}_{2} \mathrm{O}_{(\mathrm{s})} \rightarrow \mathrm{ZnO}_{(\mathrm{s})}+2 \mathrm{Ag}_{(\mathrm{s})}+{ }^{1 / 2} \mathrm{O}_{2(\mathrm{~g})}
$$

Then, this technique displayed the existence of phases mixture, that is, metallic silver and $\mathrm{ZnO}(\mathrm{Ag}-\mathrm{ZnO})$. As the positions of the $\mathrm{ZnO}$ characteristic peaks did not alter, the $\mathrm{ZnO}$ and $\mathrm{Ag}$ mixture formation was attributed to the agglomeration of $\mathrm{Ag}$ on the $\mathrm{ZnO}$ surface. This justifies the alterations in the peak intensities of the diffractograms corresponding to the $\mathrm{Ag}$ and $\mathrm{ZnO}$ phases.

The gradual decrease in the peaks intensity as well as the metallic silver amount at $600{ }^{\circ} \mathrm{C}$ and $1000{ }^{\circ} \mathrm{C}$ may be associated to the $\mathrm{Ag}$ agglomeration on $\mathrm{ZnO}$ surface, forming an amorphous species, from $350{ }^{\circ} \mathrm{C}$ to $957^{\circ} \mathrm{C}$, Reaction 4 .

$$
\mathrm{ZnO}_{(\mathrm{s})}+\mathrm{Ag}_{(\mathrm{s})} \rightarrow(\mathrm{Ag}) \mathrm{ZnO}_{(\mathrm{s})} \quad\left(350{ }^{\circ} \mathrm{C}<\mathrm{t}<957^{\circ} \mathrm{C}\right)
$$

The Ag fusion was characterized at $957^{\circ} \mathrm{C}$, Reaction 5 .

$$
\mathrm{Ag}_{(\mathrm{s})} \rightarrow \operatorname{Ag}_{(\mathrm{l})} \quad\left(\mathrm{t} \geq 957^{\circ} \mathrm{C}\right)
$$

The images, obtained by SEM, with magnification of 3,000×, showed which material heated thermally at $200{ }^{\circ} \mathrm{C}$ during $12 \mathrm{~h}$ maintained the same morphological characteristics of zinc oxalate, Figure $5 \mathrm{a}$ and was not enough to $\mathrm{ZnO}$ synthesis, as verified previously from thermal analysis, Raman scattering, and X-ray diffraction. The fissure was observed at $400{ }^{\circ} \mathrm{C}$ (not shown), that became more evident when the temperature was raised from $600{ }^{\circ} \mathrm{C}$ to $1000^{\circ} \mathrm{C}$, Figure $5 \mathrm{~b}$-d. Besides of this, the particle sizes enhanced, as well as their sinterized aspect, inset Figure 5b-d with a magnification of $60,000 \times$, decreasing the available surface area to catalytic reactions. In this way, the complete $\mathrm{ZnO}$ synthesis carried out at $600^{\circ} \mathrm{C}$, considering the incomplete burn at $400{ }^{\circ} \mathrm{C}$, observed by Raman scattering.
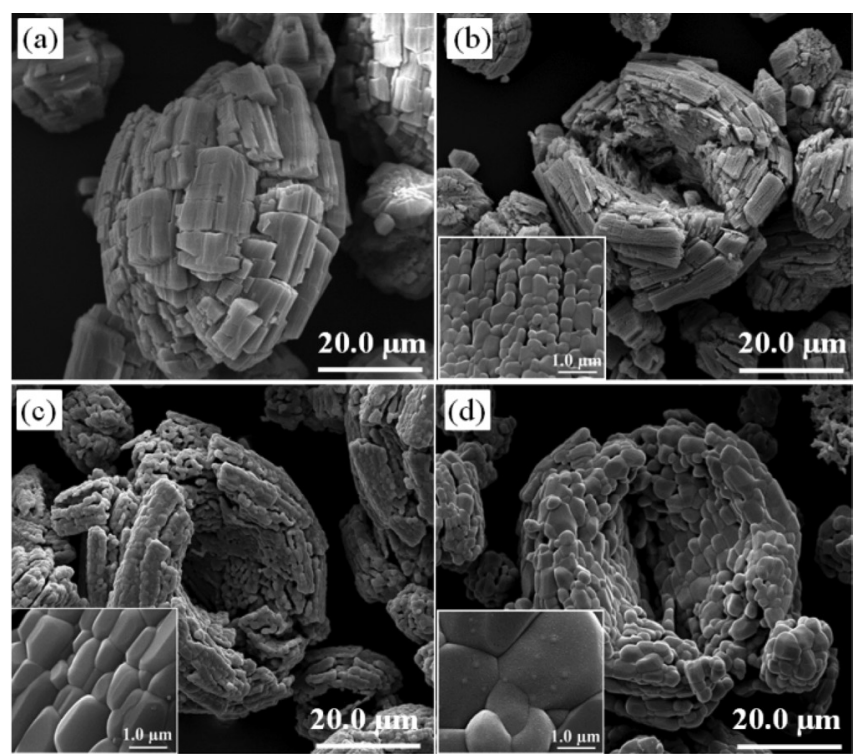

Figure 5. SEM images of (a) zinc oxalate heated thermally for $12 \mathrm{~h}$ at $(b)$ $600{ }^{\circ} \mathrm{C}$, (c) $800{ }^{\circ} \mathrm{C}$, and (d) $1000{ }^{\circ} \mathrm{C}$. Inset: (b), (c), and (d) SEM images with magnification of $60,000 \times$

The SEM images with a magnification of $3,000 \times$ of the zinc and silver oxalate mixture $\left(\mathrm{Ag}_{2} \mathrm{C}_{2} \mathrm{O}_{4}-\mathrm{ZnC}_{2} \mathrm{O}_{4}\right)$, displayed in Figure 6a, shows particles with morphology similar to the zinc oxalate, Figure 5a. Besides this, a morphologically different structure was verified and related to the silver oxalate (Figure 6a, inset 1 ), as verified by EDS. The morphological alterations of the particles, displayed in Figure $6 \mathrm{~b}-\mathrm{d}$, were established when the heat treatment was raised from $400{ }^{\circ} \mathrm{C}$ to $1000{ }^{\circ} \mathrm{C}$. The structure related to silver started to decompose from $400{ }^{\circ} \mathrm{C}$ and was distributed in two different ways: the first one, as an arrangement constituted by agglomerates, as verified from EDS, Figure $6 b$, inset. The second consisted of smaller spherical particles, also observed from EDS, Figure 6c, inset. The agglomeration increase of these structures with zinc oxide was verified at $1000^{\circ} \mathrm{C}$. The fissure opening was minimal at $400{ }^{\circ} \mathrm{C}$ and increased at higher temperatures. This means that the enhancement temperature favored the increase as in size as in the particles sintering.
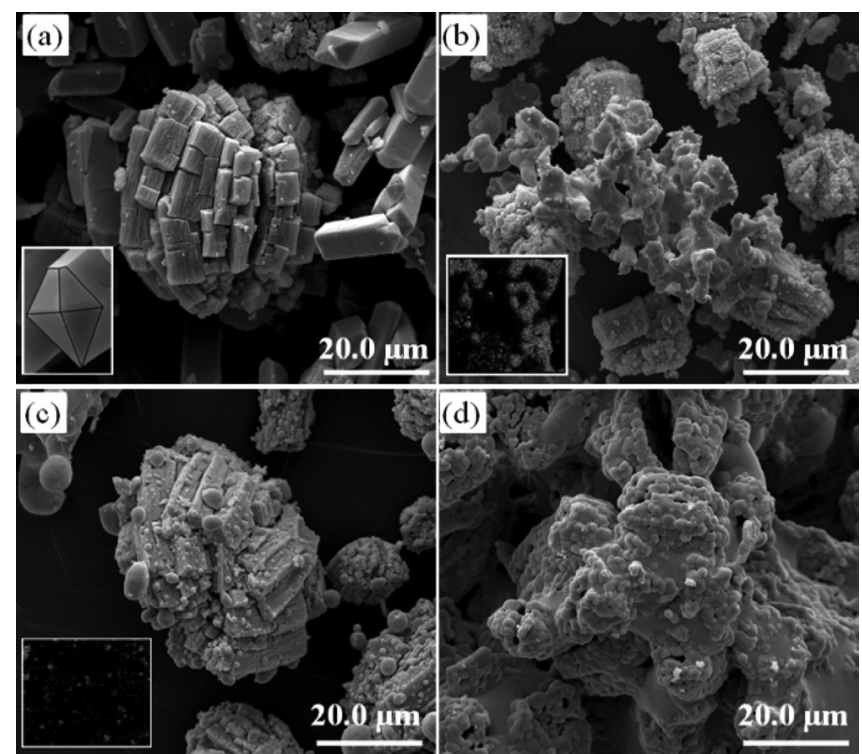

Figure 6. SEM image of (a) $\mathrm{ZnC}_{2} \mathrm{O}_{4}-\mathrm{Ag}_{2} \mathrm{C}_{2} \mathrm{O}_{4}$ sample heated at (b) $400{ }^{\circ} \mathrm{C}$, (c) $600{ }^{\circ} \mathrm{C}$, and (d) $1000{ }^{\circ} \mathrm{C}$ for $12 \mathrm{~h}$. Inset: (a) $\mathrm{Ag}_{2} \mathrm{C}_{2} \mathrm{O}_{4}$ morphology, (b) and (c) Ag distribution verified by $E D S$

Thermal treatments fulfill fundamental role in the properties of the materials during the synthesis. ${ }^{21}$ This can be justified, because at very high temperatures the sinterization facilitates the movement of atoms and molecules ${ }^{22}$ resulting in the particle size growth and in the decrease of the available specific surface area and pore volume for adsorption.

Taking into place the results obtained from TGA, Raman, and $\mathrm{XRD}$, it is expected that the smallest temperature for the material formation $\left(600{ }^{\circ} \mathrm{C}\right.$ for $\mathrm{ZnO}$ and $400{ }^{\circ} \mathrm{C}$ for $\left.\mathrm{Ag}-\mathrm{ZnO}\right)$ allows the largest available surface area. Consequently, the specific surface area and pore volume of the materials, obtained from the BET method, were carried out with the aim to verify the influence of thermal treatment in the synthesized materials. From these results, shown in Table 1, the largest values for specific surface area and pore volume were obtained from $\mathrm{Ag}-\mathrm{ZnO}$ heated thermally at $400{ }^{\circ} \mathrm{C}$ followed by $\mathrm{ZnO}$ at $600{ }^{\circ} \mathrm{C}$. It was verified that the temperature enhancement decreased the pore volume for both $\mathrm{ZnO}\left(0.52\right.$ to $\left.0.05 \mathrm{~cm}^{3} \mathrm{~g}^{-1}\right)$ and $\mathrm{Ag}-\mathrm{ZnO}$ (1.95 to 0.03 $\left.\mathrm{cm}^{3} \mathrm{~g}^{-1}\right)$, whereas the silver presence on the $\mathrm{ZnO}$ surface increased the oxide surface area $\left(10.4 \mathrm{~m}^{2} \mathrm{~g}^{-1}\right)$ in comparison to $\mathrm{ZnO}\left(5.49 \mathrm{~m}^{2}\right.$ $\left.\mathrm{g}^{-1}\right)$. In this way, the temperature enhancement decreased the specific surface area and pore volume, due to the material sinterization. These results indicate that the surface modification of $\mathrm{ZnO}$ with silver was satisfactory, since the presence of this metal decreases the formation temperature to $400{ }^{\circ} \mathrm{C}$ and approximately doubles the surface area of the semiconductor oxide. 
Table 1. Specific surface area $\left(\mathrm{S}_{\mathrm{BET}}\right)$ and pore volume $\left(\mathrm{V}_{\mathrm{p}}\right)$ for materials synthesized using different thermal treatment temperature

\begin{tabular}{lccc}
\hline Photocatalyst & $\mathrm{T} /{ }^{\circ} \mathrm{C}$ & $\mathrm{S}_{\mathrm{BET}} / \mathrm{m}^{2} \mathrm{~g}^{-1}$ & $\mathrm{~V}_{\mathrm{p}} / 10^{-2} \mathrm{~cm}^{3} \mathrm{~g}^{-1}$ \\
\hline \multirow{2}{*}{$\mathrm{ZnO}$} & 600 & 5.49 & 0.52 \\
& 800 & 1.57 & 0.10 \\
& 1000 & 2.20 & 0.09 \\
\hline \multirow{2}{*}{ Ag-ZnO } & 400 & 10.4 & 1.95 \\
& 600 & 2.60 & 0.09 \\
& 1000 & 2.77 & 0.03 \\
\hline
\end{tabular}

So, the presence of silver on the $\mathrm{ZnO}$ surface increased the specific surface area in this work, meanwhile Liang et al. ${ }^{12}$ observed a decrease of around $30 \%$ in the synthesis of porous 3D flower-like $\mathrm{Ag} /$ $\mathrm{ZnO}$ composites at $300{ }^{\circ} \mathrm{C}$ during $2 \mathrm{~h}$. Our results using $\mathrm{Ag}-\mathrm{ZnO}$ at $400{ }^{\circ} \mathrm{C}$ presented larger surface area in comparison to $\mathrm{ZnO}$ obtained at $600{ }^{\circ} \mathrm{C}\left(6.25 \mathrm{~m}^{2} \mathrm{~g}^{-1}\right)$ by Cun et al. ${ }^{23}$

The band gap energy, calculated from UV-Vis spectra of diffuse reflectance, showed that the temperature increase delocalized the material absorption to higher wavelength. ${ }^{24}$ This means that there was a decrease of the band gap energy as presented in Table 2. This behavior was observed as for $\mathrm{ZnO}$ as for $\mathrm{Ag}-\mathrm{ZnO}$, which can be related to the crystallization process. Among these materials, $\mathrm{ZnO}$ synthesized at $600{ }^{\circ} \mathrm{C}$, presented the band gap energy of $3.16 \mathrm{eV}$. Conversely, Ag- $\mathrm{ZnO}$, treated at $400{ }^{\circ} \mathrm{C}$, presented the largest value for band gap energy of $3.25 \mathrm{eV}$. The synthesized $\mathrm{ZnO}$ in this work, presented band gap energies lower than those obtained by Pardeshi and Pati ${ }^{25}$ about the $\mathrm{ZnO}$ preparation by mechanochemical synthesis, varying the temperature from $400{ }^{\circ} \mathrm{C}$ to $900{ }^{\circ} \mathrm{C}$. On the other hand, Georgekutty et al..$^{9}$ did not observe variation in the band gap energy among $\mathrm{ZnO}$ and modified by silver samples.

Table 2. Band gap energy $\left(\mathrm{E}_{\mathrm{g}}\right)$ for materials synthesized using different thermal treatment temperature

\begin{tabular}{lcc}
\hline Photocatalyst & $\mathrm{T} /{ }^{\circ} \mathrm{C}$ & $\mathrm{E}_{\mathrm{g}} / \mathrm{eV}$ \\
\hline \multirow{2}{*}{$\mathrm{ZnO}$} & 600 & 3.16 \\
& 800 & 3.05 \\
& 1000 & 3.09 \\
\hline \multirow{2}{*}{$\mathrm{Ag}-\mathrm{ZnO}$} & 400 & 3.25 \\
& 600 & 3.21 \\
& 1000 & 3.06 \\
\hline
\end{tabular}

\section{Photocatalytic activity}

The DR23 diazo dye decolorization by UV photolysis presented a kinetic behavior of first order with a rate constant of $0.13 \times 10^{-3} \mathrm{~min}^{-1}$ $(\mathrm{r}=0.898)$ at $30^{\circ} \mathrm{C}$, the DR23 solution does not have significant decolorization $(3.12 \%)$. The photocatalytic activity of the synthesized oxides was investigated under pseudo-first order conditions, maintaining fixed DR23 concentration $\left(7.5 \times 10^{-5} \mathrm{~mol} \mathrm{~L}^{-1}\right)$ in a suspension at $30^{\circ} \mathrm{C}$ as displayed in Table 3 .

According to this table, the $\mathrm{ZnO}\left(2.0 \mathrm{~g} \mathrm{~L}^{-1}\right)$, treated thermally at $600{ }^{\circ} \mathrm{C}$ for $12 \mathrm{~h}$, presented the largest decolorization rate constant, $k_{\text {obs }}$, of $3.07 \times 10^{-3} \mathrm{~min}^{-1}$. This rate constant was more than three times larger in comparison to $\mathrm{ZnO}$ heated at $800{ }^{\circ} \mathrm{C}\left(0.96 \times 10^{-3} \mathrm{~min}^{-1}\right)$ and almost six-fold larger than at $1000^{\circ} \mathrm{C}\left(0.55 \times 10^{-3} \mathrm{~min}^{-1}\right)$. Figure 7 a displays the absorption spectra of DR23 decolorization, with maximum absorbance $\left(A_{o}=1.316\right)$ at $503 \mathrm{~nm}$, after the adsorption-desorption
Table 3. Decolorization rate constant $\left(k_{o b s}\right)$ of direct red $23\left(7.5 \times 10^{-5} \mathrm{~mol} \mathrm{~L}^{-1}\right)$ in the presence of synthesized photocatalyst $\left(2.0 \mathrm{~g} \mathrm{~L}^{-1}\right)$ at $30{ }^{\circ} \mathrm{C}$

\begin{tabular}{lcccc}
\hline Photocatalyst & $\mathrm{T} /{ }^{\circ} \mathrm{C}$ & $\begin{array}{c}k_{\text {obs }} / \\
10^{-3} \mathrm{~min}^{-1}\end{array}$ & $r$ & $\begin{array}{c}\text { Decolorization / } \\
\%\end{array}$ \\
\hline \multirow{3}{*}{ ZnO } & 600 & 3.07 & 0.997 & 52.3 \\
& 800 & 0.96 & 0.944 & 21.0 \\
& 1000 & 0.55 & 0.841 & 12.2 \\
\hline \multirow{2}{*}{ Ag-ZnO } & 400 & 6.87 & 0.997 & 80.8 \\
& 600 & 1.93 & 0.993 & 38.4 \\
& 1000 & 1.09 & 0.949 & 24.4 \\
\hline
\end{tabular}
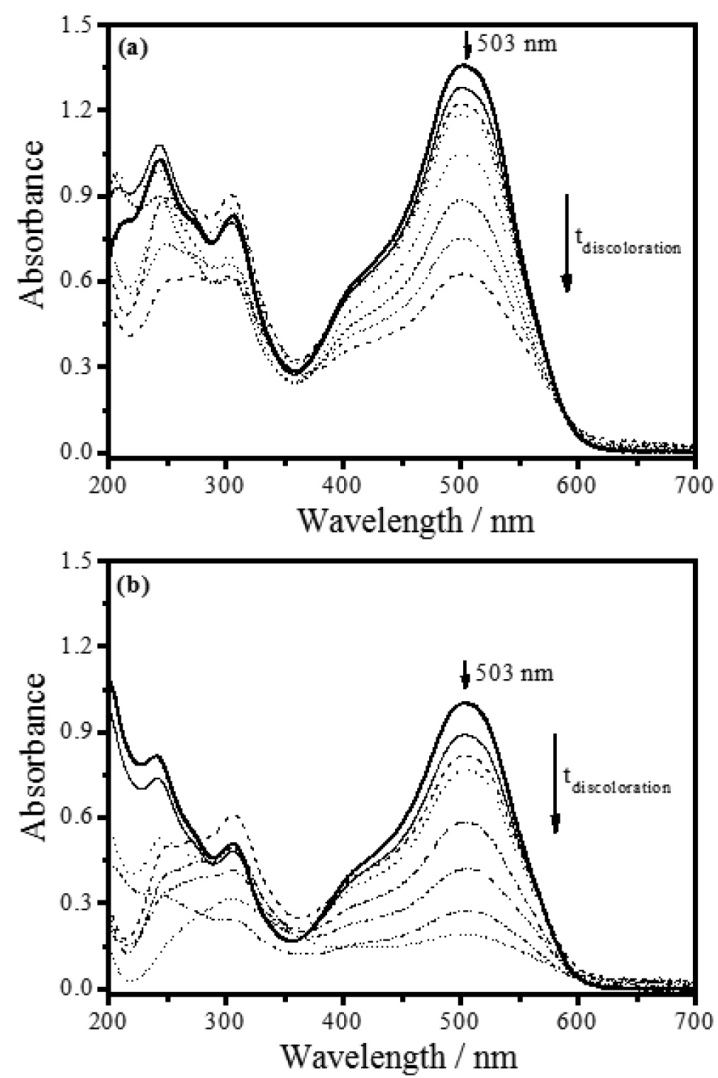

Figure 7. Direct red 23 diazo dye $\left(7.5 \times 10^{-5} \mathrm{~mol} \mathrm{~L}^{-1}\right)$ decolorization in aqueous suspension using (a) $\mathrm{ZnO}$ synthesized thermally at $600{ }^{\circ} \mathrm{C}(2.0 \mathrm{~g}$ $\left.\mathrm{L}^{-1}\right)$ and $(\mathrm{b}) \mathrm{Ag}-\mathrm{ZnO}$ synthesized thermally at $400^{\circ} \mathrm{C}\left(2.0 \mathrm{~g} \mathrm{~L}^{-1}\right)$ as a function of irradiation time at $30{ }^{\circ} \mathrm{C}$

equilibrium time of $60 \mathrm{~min}$, using $\mathrm{ZnO}$ under $\mathrm{UV}$ irradiation at $30^{\circ} \mathrm{C}$ during $240 \mathrm{~min}$.

On the other hand, when the Ag- $\mathrm{ZnO}$ composite thermally heated at $400{ }^{\circ} \mathrm{C}$ was irradiated, the diazo dye presented a larger decolorization rate constant of $6.87 \times 10^{-3} \mathrm{~min}^{-1}$ as shown in Table 3 . This value was about 3.6-fold larger with respect to $600{ }^{\circ} \mathrm{C}\left(1.93 \times 10^{-3}\right.$ $\left.\mathrm{min}^{-1}\right)$ and around 6.3-fold larger than $1000{ }^{\circ} \mathrm{C}\left(1.09 \times 10^{-3} \mathrm{~min}^{-1}\right)$. Moreover, when $\mathrm{Ag}-\mathrm{ZnO}$ was used, the initial azo dye absorbance was lower than $\mathrm{ZnO}$, decreasing to 1.001 (Figure $7 \mathrm{~b}$ ). This can be attributed to the larger specific surface area of $\mathrm{Ag}-\mathrm{ZnO}$, determined by BET. For this reason, as the rate constant as the decolorization percentage of the DR23 diazo dye were larger, when the irradiation was carried out by means of the $\mathrm{ZnO}$ in $\mathrm{Ag}$ presence $(80.8 \%$ ) in comparison to $\mathrm{ZnO}(52.3 \%)$. Therefore, the $\mathrm{ZnO}$, synthesized and heated in silver medium, presented higher values of $k_{o b s}$ due to the larger available surface area and the $\mathrm{Ag}$ presence that restrains the 
recombination of photogenerated charge carriers $\left(h_{V B}{ }^{+} / e_{C B}{ }^{-}\right)$on $\mathrm{ZnO}$ surface, because it is considered an efficient removal of electrons. This enables a larger formation of hydroxyl radicals $\left({ }^{\circ} \mathrm{OH}\right)$ from the photogenerated holes $\left(h_{V B}{ }^{+}\right)$, Reaction 6, which are capable to oxidize DR23 diazo dye by means of the hydrogen abstraction, initiating the oxidation radical reactions and mineralizing completely the diazo dye, ${ }^{1,2}$ DR23, Reaction 7.

$$
\begin{gathered}
h_{V B}{ }^{+}+\mathrm{H}_{2} \mathrm{O} \rightarrow \cdot{ }^{\cdot} \mathrm{OH}+\mathrm{H}^{+} \\
\cdot \mathrm{OH}+\mathrm{DR} 23 \rightarrow \rightarrow \mathrm{CO}_{2}+\mathrm{H}_{2} \mathrm{O}
\end{gathered}
$$

The diffuse reflectance spectra showed that the band gap energy of $\mathrm{ZnO}$ and $\mathrm{Ag}-\mathrm{ZnO}$ decreased with temperature increase, however the band gap energy decrease did not correspond to the photocatalytic efficiency of these oxides. Based on these evidences it can be inferred that the particles surface area was determinant in the photocatalytic efficiency of materials obtained at different temperatures. In according to Table 3, the photocatalytic efficiency of synthesized zinc oxide in presence of silver was larger than $\mathrm{ZnO}$. This may be justified by the synergism that occurs between $\mathrm{Ag}$ and $\mathrm{ZnO}$, considering that the metallic silver may behave as electron acceptor, hindering the charge carriers recombination, ${ }^{26}$ consequently favoring the pollutants degradation on the photocatalyst surface. Therefore, the modification of the $\mathrm{ZnO}$ surface with silver, $\mathrm{Ag}-\mathrm{ZnO}$, resulted in a viable material in comparison to $\mathrm{ZnO}$ for the application in heterogeneous photocatalysis for DR23 decolorization.

\section{CONCLUSION}

This work reported that the $\mathrm{ZnO}$ and $\mathrm{Ag}-\mathrm{ZnO}$ syntheses were carried out satisfactorily from the transition metal oxalates at 600 ${ }^{\circ} \mathrm{C}$ and $400{ }^{\circ} \mathrm{C}$, respectively. The temperature raise in the thermal treatment showed that the pore volume of the synthesized oxides decreased, owing to the particle sinterization, decreasing consequently the photocatalytic activity of these materials for decolorization of the direct red 23 diazo dye. Besides of this, the zinc oxide synthesized at silver medium, $\mathrm{Ag}-\mathrm{ZnO}$, more than doubled the decolorization rate constant $\left(6.87 \times 10^{-3} \mathrm{~min}^{-1}\right)$ with respect to $\mathrm{ZnO}\left(3.07 \times 10^{-3} \mathrm{~min}^{-}\right.$ $\left.{ }^{1}\right)$, attributed to the increase of available surface area, as well as the recombination decrease of the photogenerated charge carriers, by removal of electrons by silver, generating hydroxyl radical.

\section{ACKNOWLEDGMENTS}

The authors are grateful to Fundação Araucária (22850/2011) for financial support. A. C. Lucilha is grateful to CAPES for the scholarship. The authors would like to thank LMEM-UEL for the SEM analysis.

\section{REFERENCES}

1. Legrini, O.; Oliveros, E.; Braun, A. M.; Chem. Rev. 1993, 93, 671.

2. Hoffman, M. R.; Martin, S. T.; Choi, W.; Bahnemann, D. T.; Chem. Rev. 1995, 95, 69 .

3. Zollinger, H.; Color Chemistry: Synthesis, Properties and Applications of Organic Dyes and Pigments, $2^{\text {nd }}$ ed., VCH: Weinheim, 1991.

4. Ohtani, B.; Catalysts 2013, 3, 942.

5. Özgür, Ü.; Alivov, Y. I.; Liu, C.; Teke, A.; Reshchikov, M. A.; Doan, S.; Avrutin, V.; Cho, S.-J.; Morkoç, H.; J. Appl. Phys. 2005, 98, 041301.

6. Kumar, S. G.; Rao, K. S. R. K.; RSC Adv. 2015, 5, 3306.

7. Tian, J. J.; Zhang, Q. F.; Zhang, L. L.; Gao, R.; Shen, L. F.; Zhang, S. G.; Qu, X. H.; Cao, G.; Nanoscale 2013, 5, 936.

8. Guo, X-H.; Ma, J-Q.; Ge, H-G.; J. Phys. Chem. Solids 2013, 74, 784.

9. Georgekutty, R.; Seery, M. K.; Pillai, S. C.; J. Phys. Chem. C 2008, 112, 13563.

10. Zheng, Y.; Zheng, L.; Zhan, Y.; Lin, X.; Zheng, Q.; Wei, K.; Inorg. Chem. 2007, 46, 6980 .

11. Zhai, H.; Wang, L.; Sun, D.; Han, D.; Qi, B.; Li, X.; Chang, L.; Yang, J.; J. Phys. Chem. Solids 2015, 78, 35.

12. Liang, Y.; Guo, N.; Li, L.; Li, R.; Ji, G.; Gan, S.; Appl. Surf. Sci. 2015, $332,32$.

13. Bouzid, H.; Faisal, M.; Harraz, F. A.; Al-Sayari, S. A.; Ismail, A. A.; Catal. Today 2015, 252, 20.

14. Lucilha, A. C.; Bonancêa, C. E.; Barreto, W. J.; Takashima, K.; Spectrochim. Acta, Part A 2010, 75, 389

15. Muruganandham, M.; Chen, I. S.; Wu, J. J.; J. Hazard. Mater. 2009, 172, 700.

16. Kubelka, P.; Munk-Aussig, F.; Tech. Phys. 1931, 12, 593.

17. Atkins, P.; de Paula, J.; Physical Chemistry, $7^{\text {th }}$ ed., Oxford: Oxford, 2006.

18. Ahmad, T.; Vaidya, S.; Sarkar, N.; Ghosh, S.; Ganguli, A. K.; Nanotechnology 2006, 17, 1236.

19. Fazio, E.; Patanè, S.; Scibilia, S.; Mezzasalma, A. M.; Mondio, G.; Neri, F.; Trusso, S.; Curr. Appl. Phys. 2013, 13, 710.

20. Ni, L.; J. Mater. Sci. Technol. 2011, 27, 563.

21. Skoog, D. A.; Holler, F. J.; Nieman, T. A.; Princípios de análise instrumental, $5^{\text {th }}$ ed., Bookman: Porto Alegre, 2002.

22. Ali, G. M.; Chakrabarti, P.; Appl. Phys. Lett. 2010, 97, 031116.

23. Cun, W.; Jincai, Z.; Xinming, W.; Bixian, M.; Guoying, S.; Ping'an, P.; Jiamo, F.; Appl. Catal., B 2002, 39, 269.

24. Rusdi, R.; Rahman, A. A.; Mohamed, N. S.; Kamarudin, N.; Kamarulzaman, N.; Powder Technol. 2011, 210, 18

25. Pardeshi, S. K.; Patil, A. B.; J. Mol. Catal. A: Chem. 2009, 308, 32.

26. Ida, Y.; Watase, S.; Shinagawa, T.; Watanabe, M.; Chigane, M.; Inaba, M.; Tasaka, A.; Izaki, M.; Chem. Mater. 2008, 20, 1254. 